\title{
Bearing Capacity Behavior of Skirted Foundations on Unsaturated Soils
}

\author{
Muthana S. Mohammed ${ }^{1, a}$, Mahmood R. Mahmood ${ }^{1, b^{*}}$, and Saad F. A Al-Wakel ${ }^{1, c}$ \\ ${ }^{1}$ Department of Civil Engineering, University of Technology-Iraq, Baghdad, Iraq. \\ amahmoudal_qaissy@yahoo.com, ${ }^{\text {b }}$ saadfaik231@yahoo.com, ${ }^{c}$ eng7517@gmail.com
}

\begin{abstract}
One of the most important factors for designing a safe foundation is the amount of bearing soil capacity and allowable settlement according to the type of structure. Therefore, in geotechnical engineering, the aim is to improve foundations' bearing capacity in many ways, some of which are expensive, and the other section is difficult to implement in some sites. Skirted foundations consider as an ideal solution to improve cost-wise soil tolerance by reducing materials and installation time. At present, there are several applications, including offshore platforms, bridges, turbines, oil installations, and high-load facilities. This paper investigates the behavior of carrying capacity of skirted foundations through experimental models on the sand. To examine the effect of various saturation conditions, various ratios of length to width of the footing base at different relative densities and different conditions for saturations dry, saturated, and partially saturated soils are considered. It was found that the magnitude of soil bearing enhances with increasing ratios of length to the width of the base of the footings for all cases. The increase in performance ratio increased linearly to 1.5 in footing depth $(\mathrm{D} / \mathrm{B})$ and then decreased according to the test results after this point.
\end{abstract}

Keywords: Skirt footing; skirt depth, partially saturation; bearing capacity; matric suction.

\section{Introduction}

Al-Aghbari and Mohamedzein [1] formulated the updated load-carrying capacity equation for skirted strip foundations on sand. A series of tests on foundation models have been conducted to assess the factors affecting skirt foundations' carrying capacity. Several variables, including base friction, depth of skirt, the roughness of the skirt, stiffness, and compressibility of the soil, were studied and incorporated into the proposed equation. The results for the proposal were compared with those for foundations without skirts obtained from Terzaghi, Meyerhof, Hansen and Visic. The comparison showed that the use of structural skirts could increase the load capacity by a factor of 10 depending on the geometric and structural properties of the skirts (1.5-3.9). Nazer and El Sawwaf [2] the ultimate bearing capacity of a circular foundation sitting on confined sand was investigated using laboratory model studies. Cell width, foundation embedded depth, cell height, and depth to the top of the cell were all investigated. The results show that the enclosure of sand increases the load capacity. Al-Aghbari and Mohamedzein [3] showed the results of a circle footing experiment with a skirted resting on sand have shown that this type of reinforcement increases its capacity to carry and changes its load-displacement behavior. It recommends the use of skirt factors, considering the variables affecting the loading capacity. They are integrated with a generally acceptable potential equation for shallow circular sand foundations. The use of skirts was found to reduce the settlement of surface basements in comparison to skirts.

Al-Aghbari [4] showed the settlements with and without circular foundations had been investigated. The skirts have a big effect on the sand settlement reduction and the actions of the foundation. The study shows that the settlement mitigation factor for a certain skirt depth decreases as pressure increases. Salih and Joseph [5] showed that the effect of providing a structural skirt on bearing capacity and settlement in uniform and non-uniform sand conditions was researched using a square foundation model with various parameters such as foundation depth (Df), skirt height (d), distance from the foundation's edge to the point where the interface meets the foundation's base (x), and angle of loading (y). Golmoghani and Rowshanzamir [6] studied the effect of skirt rigidity and profundity on skirting models' bearing capacity. The results of the experiments were then compared with different bearing capacity equations. In order to increase footing capacity up to 3.68 times, the 
use of the structural skirts was observed. Both considerations that have to be taken into account are the skirt and foot's geometry and structural requirements, the soil properties, and conditions of both the soil skirt and the soil foundation interfaces. Fattah et al. [7] study the behavior of foundations bounded by a barrier of various depths and located at different distances from a sand-based foundation was studied. The relative density of sand $(33 \%, 56 \%$, and $75 \%)$, foundation form (strip, rectangle, and rectangular), wall depth to foundation width ratio $(\mathrm{D} / \mathrm{B}=0.5,1,1.5$, and 2$)$, and distance from the wall to the foundation edge are among the parameters tested thickness-to-foundation width ratio $(\mathrm{H} / \mathrm{B}=0,0.5,1,1.5$, and 2$)$. The study indicates that the existence of a barrier has a major effect on bearing capacity values. At $\mathrm{H} / \mathrm{B}=0.5$ and $\mathrm{D} / \mathrm{B}=2$, the maximum increase in bearing capacity for strip, square, and rectangular foundations bounded by a wall was $37 \%, 43 \%$, and $34 \%$ in loose sand, and $25 \%, 56 \%$, and $33 \%$ in medium dense sand, respectively, while in dense sand, it was $59 \%, 67 \%$, and $52 \%$ for strip, square, and rectangular footing, respectively, at $\mathrm{H} / \mathrm{B}=0.5$ and. The load-bearing capacity of foundations on the sand of varying relative densities increases with wall length, with the wall's maximum effect on bearing capacity occurring when the wall depth ranged between (1.5-2).

Chandrawanshi, et al. [8], conducting a model test on a ring foundation central to moderate dense sand and without skirts of varying heights and diameters, a sample test was carried out in a model tank. The unconfined case findings were contrasted with the confined case. The pressure was measured for an area of $5 \mathrm{~mm}$ (i.e., $10 \% \mathrm{~S} / \mathrm{D}$ ratio). When the sand has been confined to rocks, the lateral displacement of the sand under the foot is restricted. El Wakil [9] performed laboratory tests on circular steel footings of different diameters to analyze the effect of skirts on shallow footings' bearing capacity. The effect of sand density and skirt length on the ultimate load achieved was studied. For his study conditions and variables, the skirt increased the ultimate load of shallow footings by up to 6.25 times, demonstrating that it improved shallow foundations' resistance to applied loads. The relative density of sand and the ratio of skirt length to footing diameter also affect skirted footing performance. Arekal et al. [10] study the effect of vertical inserts or skirts on shells' bearing capacity or bucket basements on c- $\varphi$ soils. The load settlement curve showed that vertical insertions' thickness and depth enhance the bearing capacity up to eight times. The shape of the footing also has an effect on the bearing capacity of C- $\Phi$ soil. The capacity to carry square skirted legs has increased more than circular and rectangular footings with vertical insertions.

Mahmood [11] conducted plain strain model tests on sand beds with different distributions of particle sizes prepared in a loose condition of (Dr. $30 \%$ ). A strip footing model with a skirt has been assembled and loaded upright until it fails at different $\mathrm{D} / \mathrm{B}$ width ratios at the skirt depth $(0.5,1.0$, $1.5,2$, and 3). Based on test results, the improvement ratio increased straightly up to $\mathrm{D} / \mathrm{B} 1.5$ and then decreased. To perform general bearing capacity equation, two factors were introduced to calculate the bearing capacity of the skit foundation. These factors are 1.6 for skirt ratio between 0.5 to 1.5 and 1.25 for skirt ratios above 1.5. Most of the previous studies that dealt with this topic did not address the study of improving the amount of soil bearing capacity with skirt foundations in the case of saturated and partially saturated soils, so this study deal with soil improvement for structural foundations in saturated and partially saturated soils and compared them with dry soils with a lengthto-width ratio of the foundation up to 3 . The effect of increasing the length to the width will be taken in all cases of soil saturation conditions and different proportions of the relative density of sand.

\section{Test Program Materials}

Unsaturated soil is generally a three-phase combination (solids, air, and water), but a contractile skin or air-water interface is a reasonable explanation for a fourth phase. There are several reasons. The skin is a contractile membrane intertwined in the vacuum of the soil, which is used between the air and water phases as a barrier. Soil suction is a significant property of unsaturated soil, which can be defined as suction and negative stress in pore water. Porous materials are usually important to the attraction and retention of water. In the engineering sector, the suction of soil is made up of two components, osmotic and matric suction. Direct soil suction measurement or indirect matric suction measurement are two ways of measuring the suction of unsaturated soil [12]. 
The properties of the soil. Baghdad-Abu Nawas field provided the sandy river soil. Soil classification is designated by the letters SP. However, according to USCS, Figure 1 shows the soil's grain size distribution, which was determined using the ASTM D422-00 soil particle size analysis. Table 1 summarizes the physical characteristics of the soil used in this study.

Table 1. The sand's physical properties.

\begin{tabular}{|l|c|c|}
\hline Index property & Value & Specification \\
\hline $\mathrm{D} 10(\mathrm{~mm})$ & 0.16 & - \\
\hline $\mathrm{D} 30(\mathrm{~mm})$ & 0.21 & - \\
\hline D60 $(\mathrm{mm})$ & 0.29 & - \\
\hline Cu and Cc & 1.71 and 0.89 & - \\
\hline Specific gravity, Gs & 2.65 & ASTM D854-00 [13] \\
\hline Maximum dry unit weight $\left(\mathrm{kN} / \mathrm{m}^{3}\right)$ & 17 & ASTM D4253-00 [14] \\
\hline Minimum dry unit weight $\left(\mathrm{kN} / \mathrm{m}^{3}\right)$ & 14.6 & ASTM D4254-00 [15] \\
\hline Relative density. Dr $(\%)$ & 30,50 , and 70 & - \\
\hline
\end{tabular}

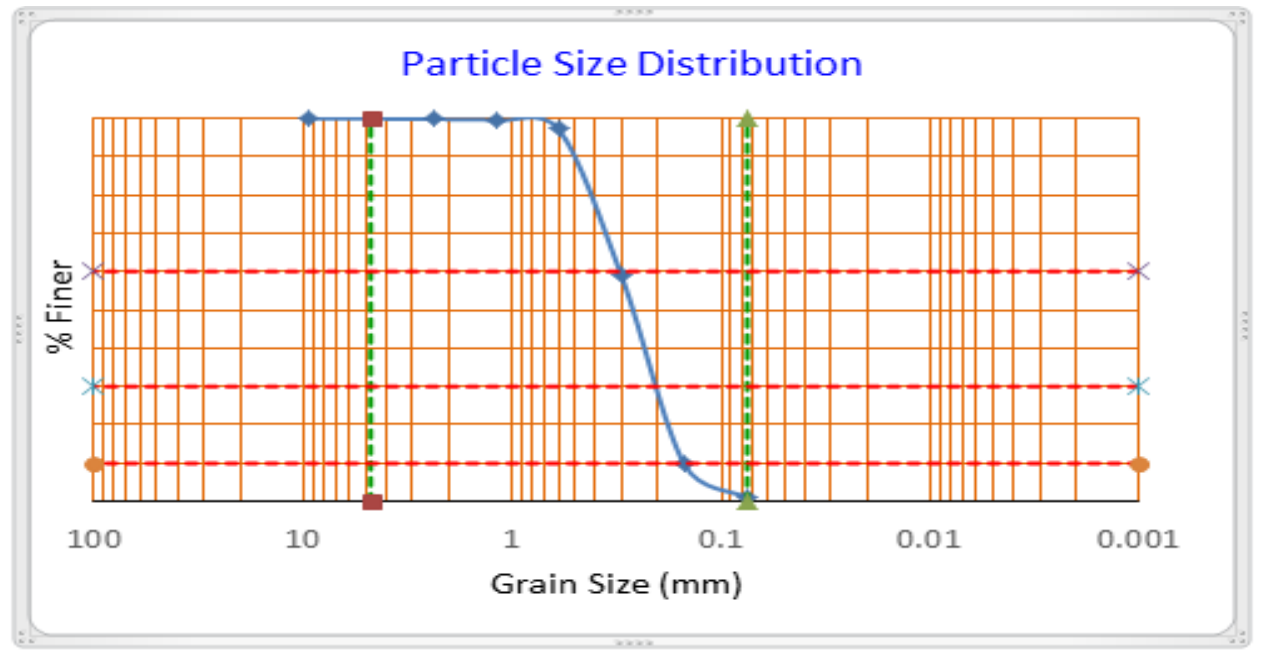

Figure 1. The soil's grain size distribution.

Skirted Foundation Models. A foundation model was manufactured, as shown in Figure 2. It includes a steel strip footing and steel plates extending from all sides. The strip footing model of 5 $\mathrm{cm}$ in width, $25 \mathrm{~cm}$ in length and $0.3 \mathrm{~cm}$ thickness. It is fixed with the skirt plate through threaded holes, the holes distributed on the skirt plate at equal distances to obtain different $\mathrm{L} / \mathrm{B}$ ratios by turning the screw bolt locations.

Test System. The device shown in Figure 2 is used for all skirted model inspections. The device comprises a soil box, a steel frame, a load cell, and a load indicator (saturation, drainage). The compression load of the skirted base model is tested by a ( 1 ton) load cell. A strain control screw jack, which is attached to an AC-controlled engine at different speeds, operates the appropriate vertical load in compression. The rate of loading is $0.5 \mathrm{~mm}$; the optical dial gauge calculates the compression settlement.

Method of Installation Skirted Foundation Model. After finished the final layer of the bed floor and filter layer, the skirted was pushed into the soil until the footing seated on the soil surface. The magnetic holder fitted to the container's sides, dial gages of $(0.01 \mathrm{~mm})$ precision were fixed on the footing edges. On the other hand, the soil should not be deformed during installation, and Figure 3 shows the foundation model's installation. 


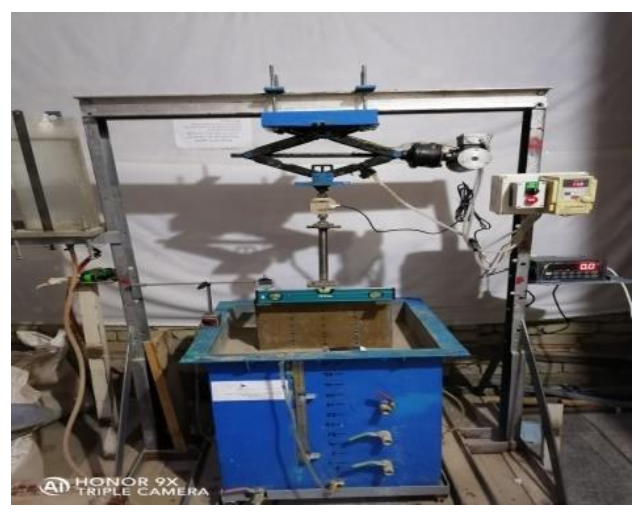

Figure 2. Setup of the physical model.

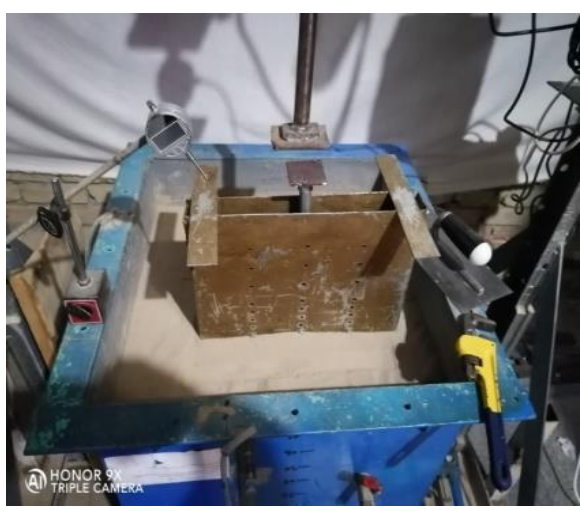

Figure 3. Installation skirted foundation model.

Model of Suction Profile Setup for Partially Saturated Soil. The changes in suction profile are due to water level changes. The process was repeated by lowering the water level under the soil surface to various depths $(150,300$, and $450 \mathrm{~mm})$. Matrix suction is tested after 24 hours, as previously stated and explained. As the water table value decreases, the matric suction rises. The tensiometer, with its accessories, and the profile suction test in three stages are depicted in Figure 4.
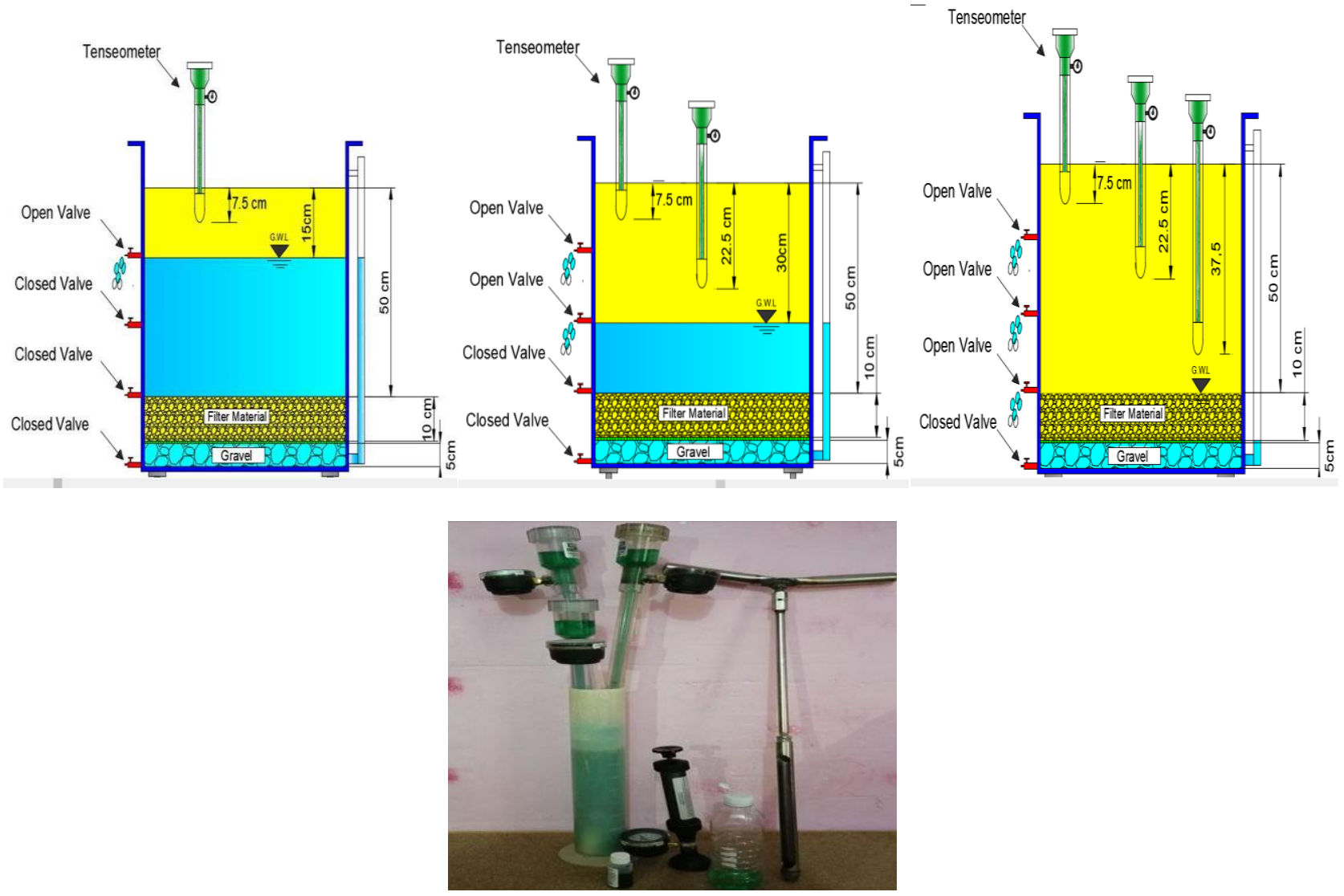

Figure 4. Tensiometers with their accessories and the profile suction test.

\section{Research Results and Discussion}

A total of 90 load-settlement model tests were carried out to find out, experiment, and evaluate the response of skirted foundations in dry, completely saturated, and partially saturated sandy soil subjected to vertical loads. The experimental samples were divided into three categories: 18 dry loose sand model tests, 18 fully saturated loose, medium, and dense sand model tests, and 54 partially saturated loose, medium, and dense sand model tests, with three levels of water lowering the water table. The results of all experiments carried out in order to understand the effects of changes in soil 
saturation on skirt foundations with different (L/B ratio) are presented in this study. Tables 2 to 4 show the average matric suction for loose, medium, and dense sand.

Table 2. The average matric suction for loose sand results

\begin{tabular}{|c|c|c|c|}
\hline $\begin{array}{c}\text { Soil saturation } \\
\text { case }\end{array}$ & $\begin{array}{c}\text { Lowering of water table from the top } \\
\text { of soil (mm) }\end{array}$ & $\begin{array}{c}\text { The average matric } \\
\text { suction (kPa) }\end{array}$ & $\begin{array}{c}\text { Average grav. water } \\
\text { content }(\mathbf{\%})\end{array}$ \\
\hline Fully saturated & 0 & 0 & 0 \\
\hline \multirow{2}{*}{$\begin{array}{c}\text { Partially } \\
\text { Saturation }\end{array}$} & 150 & 6.5 & 16.4 \\
\cline { 2 - 4 } & 300 & 7.3 & 14.3 \\
\hline
\end{tabular}

Table 3. The average matric suction results for medium sand.

\begin{tabular}{|c|c|c|c|}
\hline Soil saturation case & $\begin{array}{c}\text { Lowering of water table from the } \\
\text { top of soil (mm) }\end{array}$ & $\begin{array}{c}\text { The average matric } \\
\text { suction } \mathbf{( k P a )}\end{array}$ & $\begin{array}{c}\text { Average grav. water } \\
\text { content }(\boldsymbol{\%})\end{array}$ \\
\hline Fully saturated & 0 & 0 & 0 \\
\hline \multirow{3}{*}{$\begin{array}{c}\text { Partially } \\
\text { Saturation }\end{array}$} & 150 & 7.6 & 18 \\
\cline { 2 - 4 } & 300 & 8.4 & 16.2 \\
\cline { 2 - 4 } & 450 & 11.4 & 14 \\
\hline
\end{tabular}

Table 4. Average matric suction results for dense sand.

\begin{tabular}{|c|c|c|c|}
\hline Soil saturation case & $\begin{array}{c}\text { Lowering of water table from the } \\
\text { top of soil }(\mathbf{m m})\end{array}$ & $\begin{array}{c}\text { The average matric } \\
\text { suction (kPa) }\end{array}$ & $\begin{array}{c}\text { Average grav. water } \\
\text { content (\%) }\end{array}$ \\
\hline Fully saturated & 0 & 0 & 0 \\
\hline \multirow{3}{*}{$\begin{array}{c}\text { Partially } \\
\text { Saturation }\end{array}$} & 150 & 4.4 & 11 \\
\cline { 2 - 4 } & 300 & 5.45 & 9.5 \\
\cline { 2 - 4 } & 450 & 7.62 & 6.9 \\
\hline
\end{tabular}

Dry Sand. Eighteen experimental model tests were carried out on strip foundations (L/B from 0, 0.5, $1.0,1.5,2.0$, and 3.0) with and without skirts to examine the conduct of skirted foundations on dry clean sand. The soil bed was prepared at a relative density of 30,50 , and $70 \%$ (i.e., loose, medium, and dense sand). Load carrying capacity (a load of failure) is taken as a load corresponding to a settlement equivalent to $10 \%$ of the foundation width for all model tests, as suggested by Terzaghi. For comparison purposes, three experiments were carried out on a foundation without a skirt as a reference. The load-settlement curve for $(\mathrm{L} / \mathrm{B}=0)$ represents the case of foundation on soil without a skirt. Figures 5-7 illustrate the load-settlement relationship of skirt foundation. Each Figure is plotted for constant foundation width and different skirt lengths. The figures show that the effect of the skirt, which improvement increase as L/B increase for all the sand states but at different ratios.

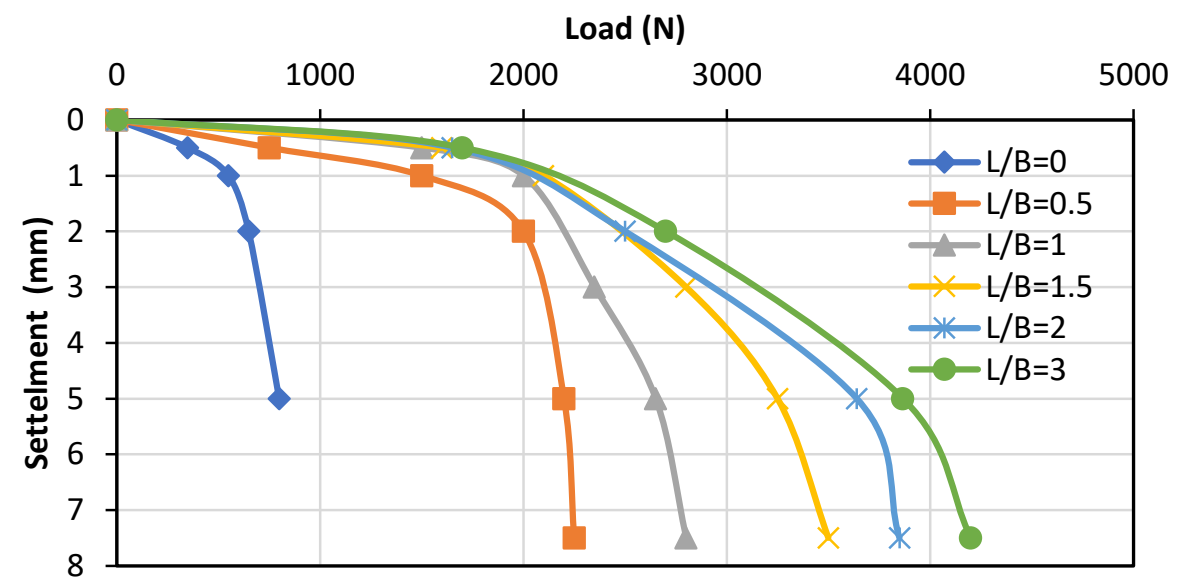

Figure 5. Load versus settlement of skirt foundation resting on dry loose sand of $(\mathrm{Dr}=30 \%)$. 


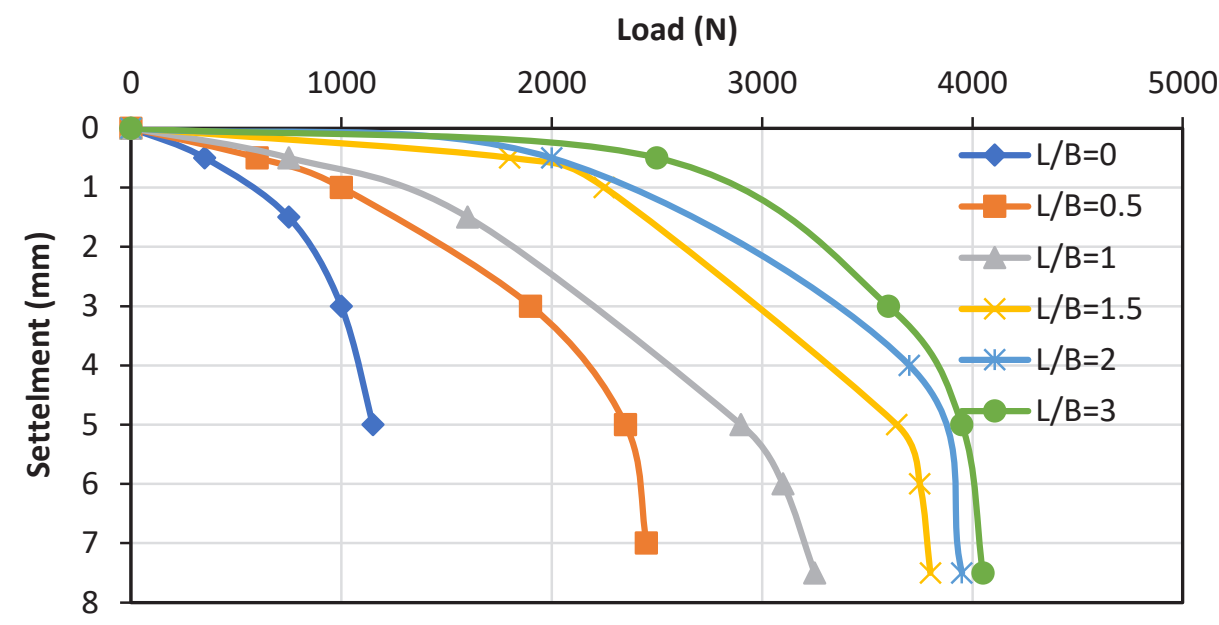

Figure 6. Load versus settlement for foundation resting on dry medium sand with $(\mathrm{Dr}=50 \%)$.

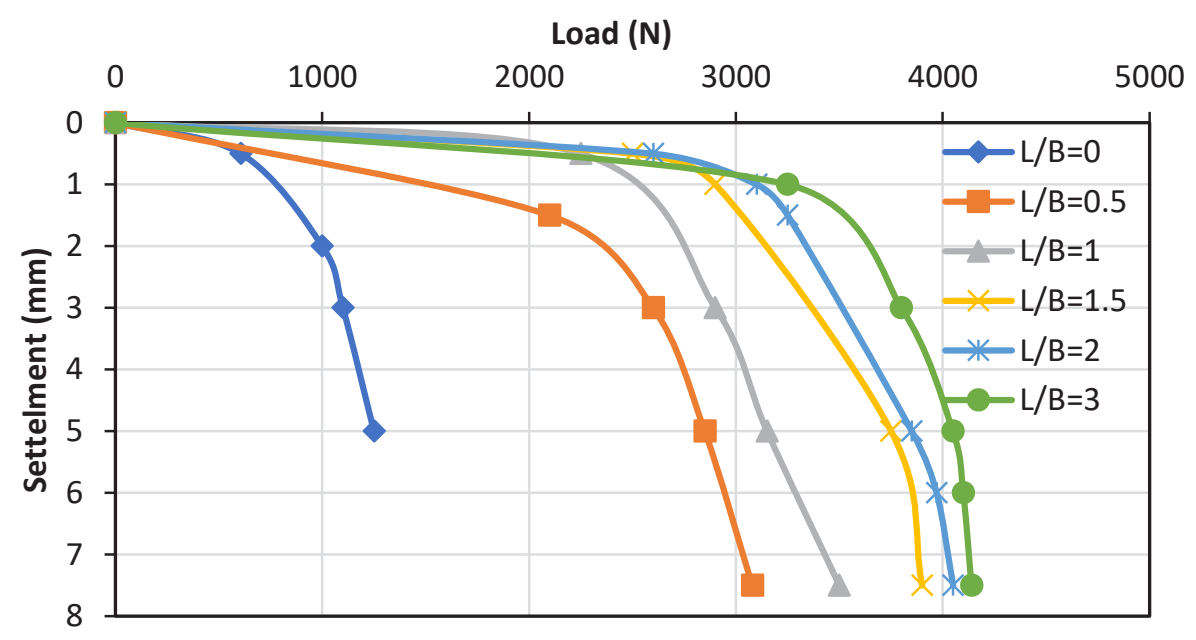

Figure 7. Load versus settlement for foundation resting on dry dense sand with ( $\mathrm{Dr}=70 \%)$

Saturated Sand. Eighteen experimental model tests on steel strip model foundations with different skirted lengths were performed to research the action of skirted foundations on saturated sand. The foundation on the sand bed under fully saturated conditions was at a degree of saturation ( $\mathrm{Sr} .100 \%)$. The soil bed is also prepared at a relative density of $30 \%, 50 \%$, and $70 \%$. The results are shown in Figures 8-10. The figures for all sand stats clarify the ultimate bearing capacity enhancement with increasing skirt length and the increment ratio more than the dry state.

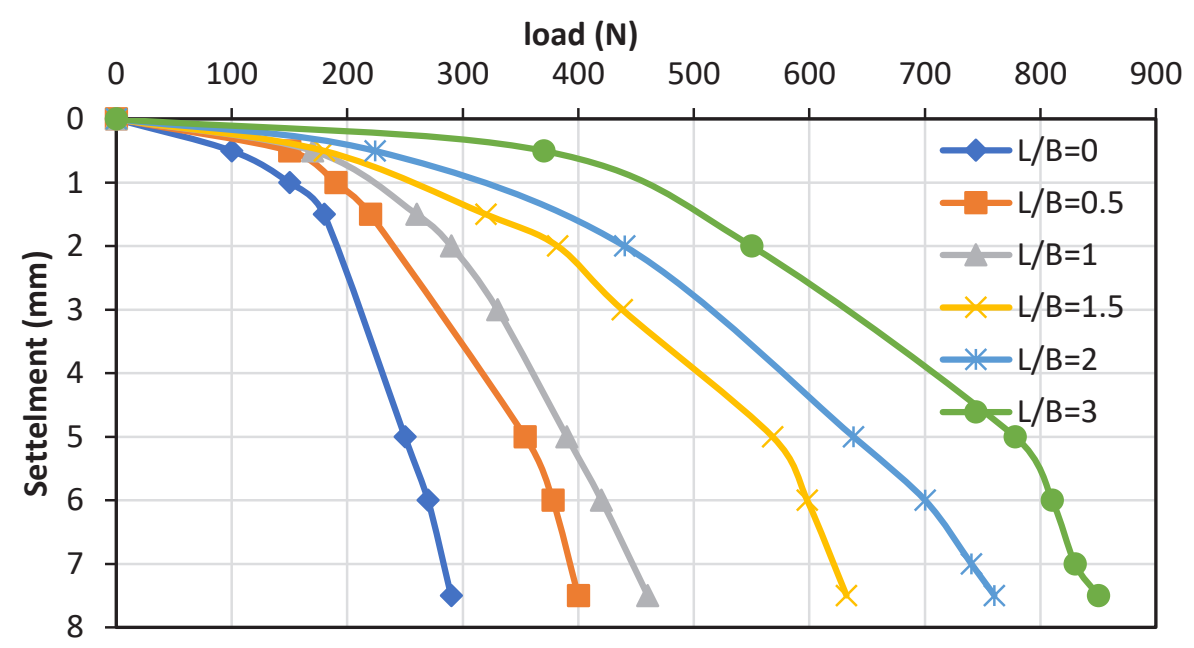

Figure 8. Load versus settlement for foundation resting on saturated loose sand with $(\mathrm{Dr}=30 \%)$. 


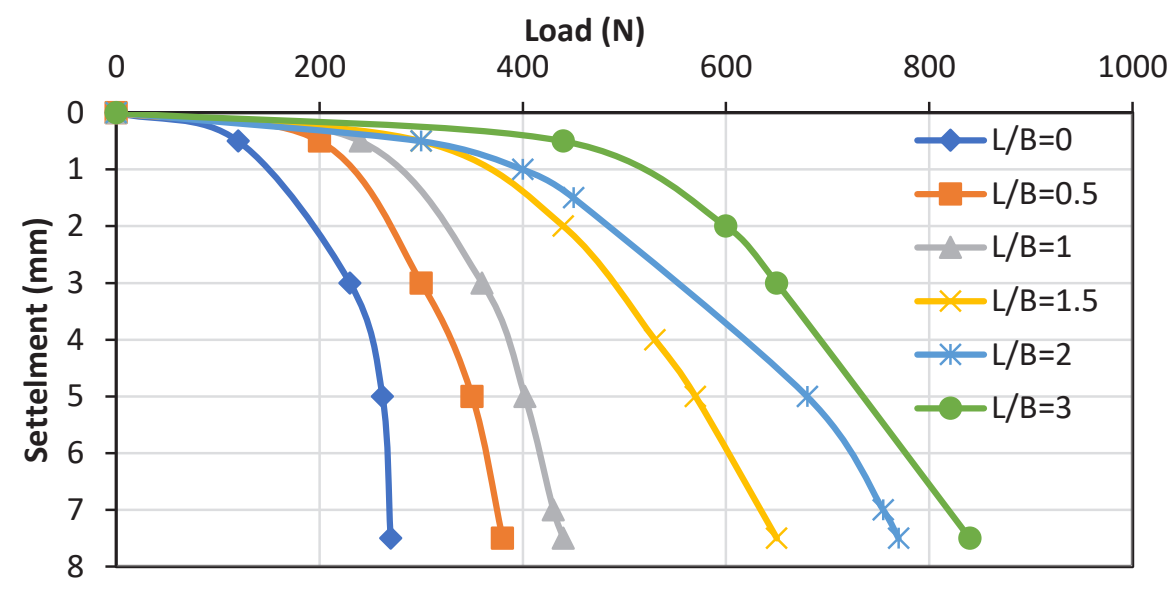

Figure 9. Load versus settlement for foundation resting on saturated medium sand with $(\mathrm{Dr}=50 \%)$.

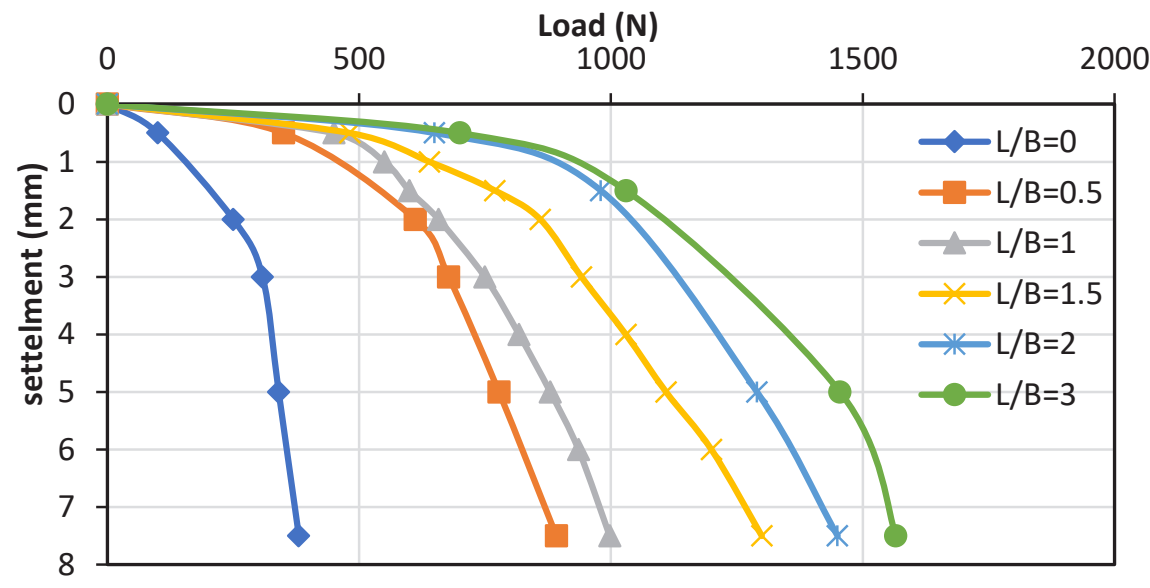

Figure 10. Load versus settlement for foundation resting on saturated dense sand with $(\mathrm{Dr}=70 \%)$.

\section{Partially Saturated Sand}

Partially saturated loose sand. Eighteen models verifying testing were performed on foundations with skirt on partially saturated soils of loose state sand. Figures 11-13 illustrate the loadsettlement curves with different matrix suction, Figure 11 for matrix suction of $7.6 \mathrm{kPa}(150 \mathrm{~mm}$ lowering of W.L), Figure 12 for matric suction of $8.4 \mathrm{kPa}(300 \mathrm{~mm}$ lowering W.L), and Figure 13 for matric suction of $11.4 \mathrm{kPa}(450 \mathrm{~mm}$ lowering W.L). All the figures show an increment of ultimate load-bearing capacity with increasing skirt length and increasing matrix suction.

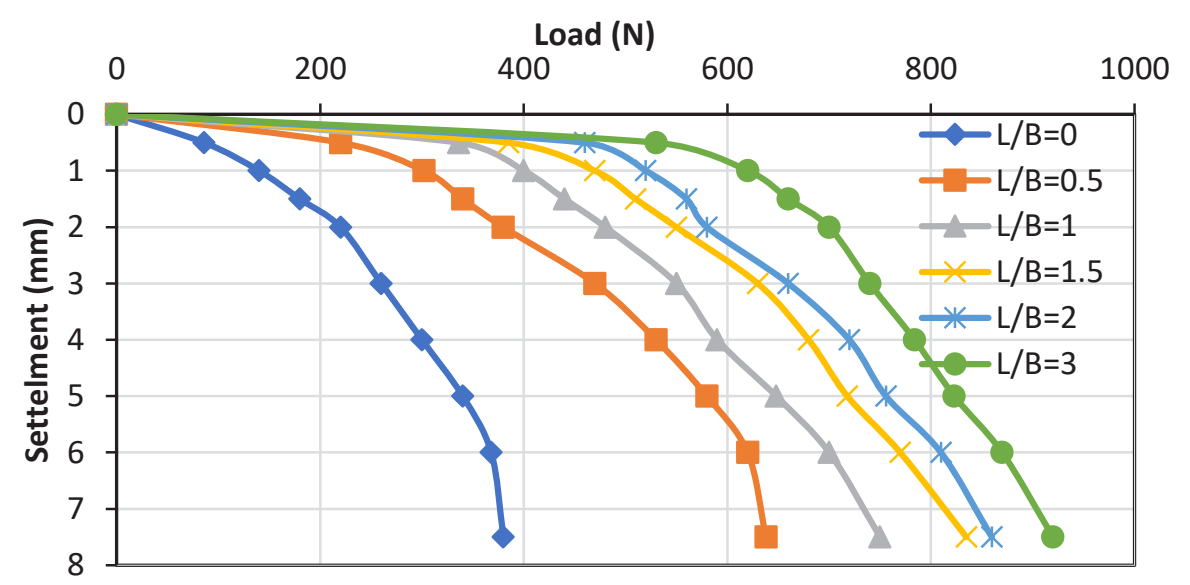

Figure 11. Load versus settlement for foundation resting on partially saturated loose sand with $(\mathrm{Dr}=30 \%)$ and matric suction $(7.6 \mathrm{kPa})$. 


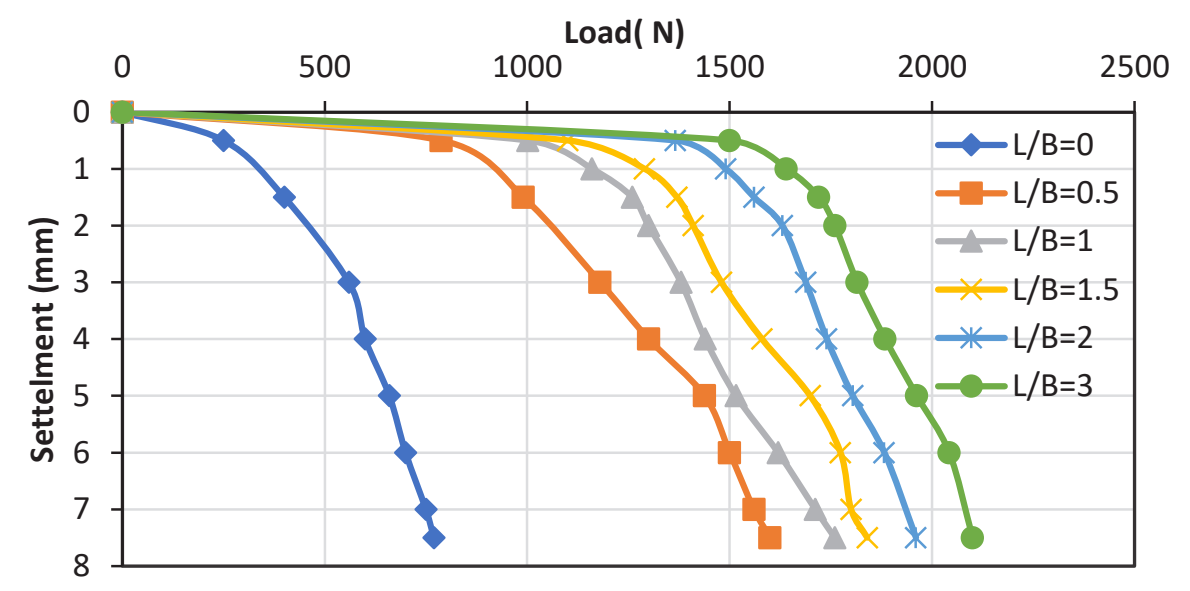

Figure 12. Load versus settlement for foundation resting on partially saturated loose sand with $(\mathrm{Dr}=30 \%)$ and matric suction $(8.4 \mathrm{kPa})$.

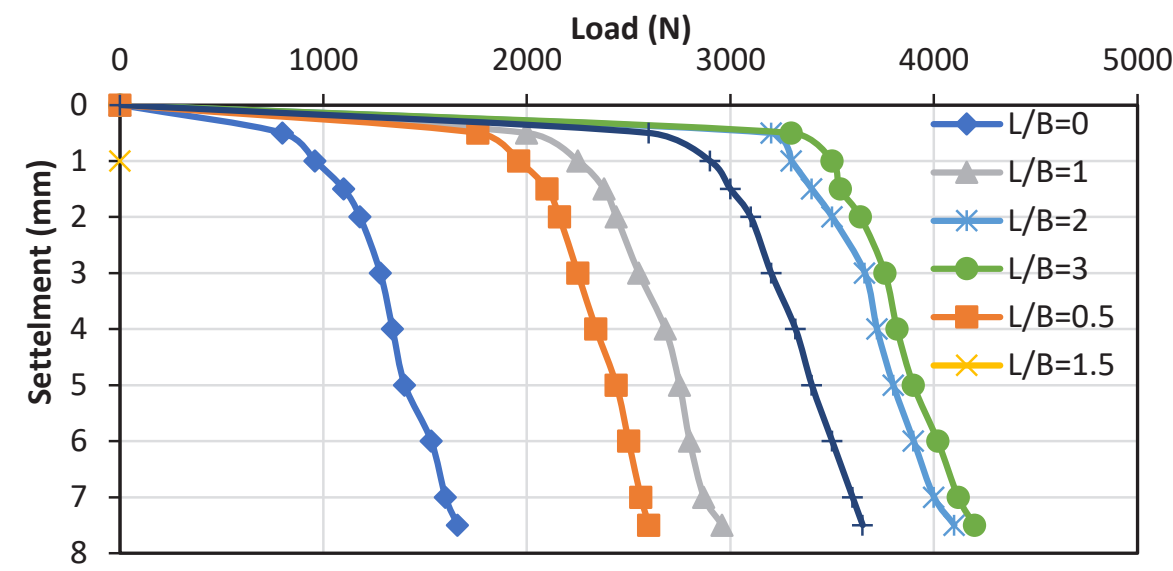

Figure 13. Load vs. settlement for foundation resting on partially saturated loose sand with $(\mathrm{Dr}=30 \%)$ and matric suction $(11.4 \mathrm{kPa})$.

Partially saturated medium sand. Eighteen model experiments were performed on foundations with a skirt on medium dense sand. Figures (14-16) illustrate the relation between the load and settlement of foundations. Each Figure is plotted for different length to width ratio and different matrix suction Figure (14) for matric suction of $6.5 \mathrm{kPa}$ (150 lowering the W.L), Figure (15) for matric suction of $7.3 \mathrm{kPa}(300 \mathrm{~mm}$ lowering W.L), and Figure (16) for matric suction of $9.5 \mathrm{kPa}(450$ lowering the W.L). All the figures show that the increment in ultimate load-bearing capacity more than that of loose sand.

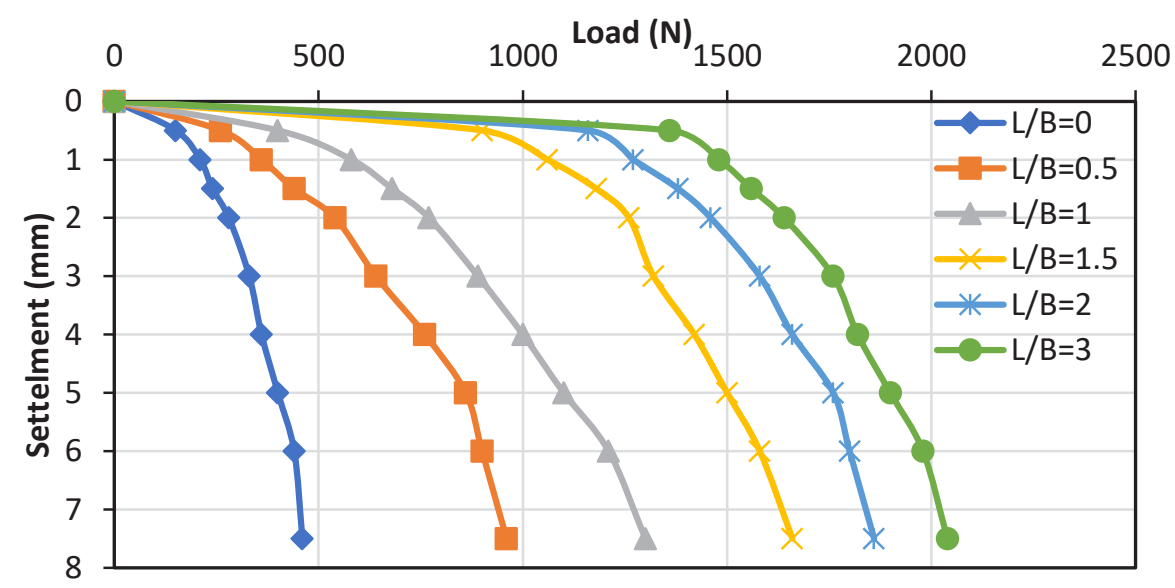

Figure 14. Load versus settlement for foundation resting on partially saturated medium dense sand with $(\mathrm{Dr}=50 \%)$ and matric suction $(6.5 \mathrm{kPa})$ 


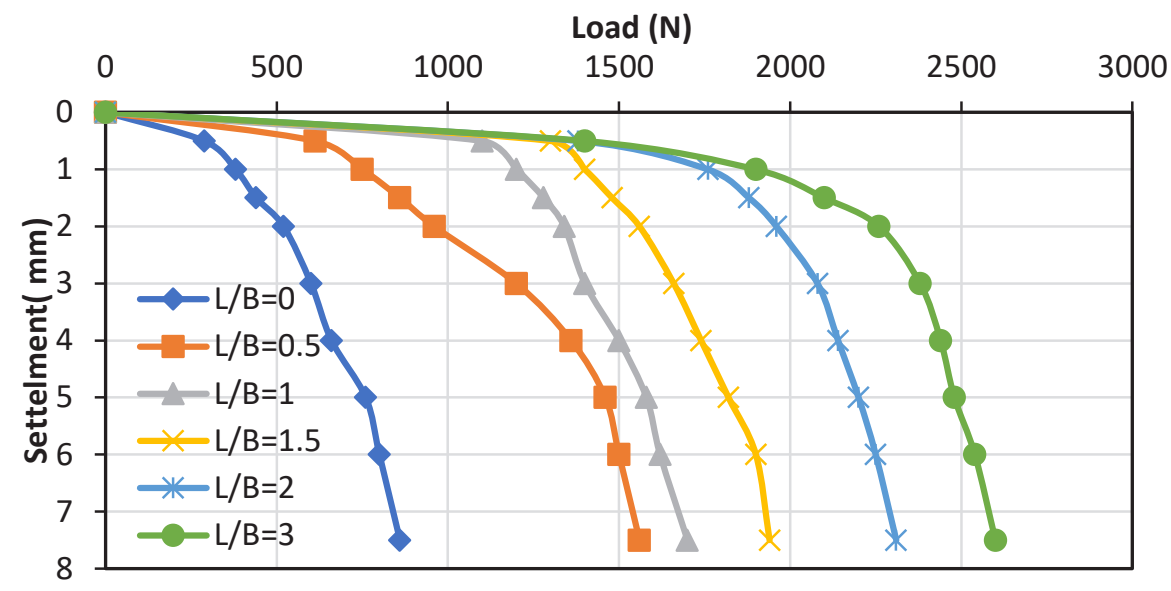

Figure 15. Load versus settlement for foundation resting on partially saturated medium dense sand with $(\mathrm{Dr}=50 \%)$ and matric suction $(7.3 \mathrm{kPa})$.

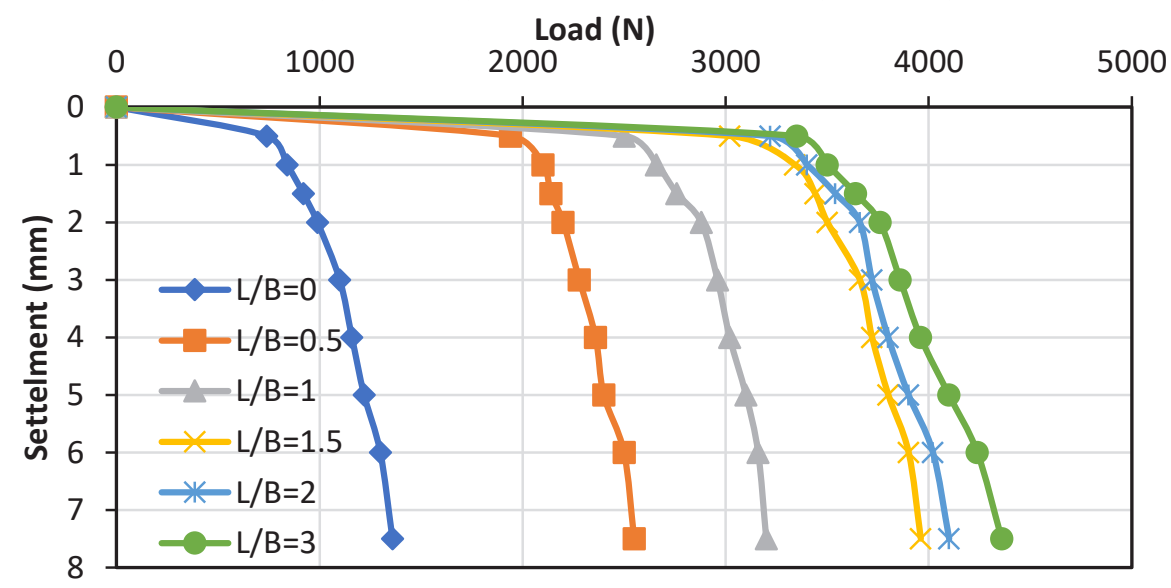

Figure 16. Load vs. settlement for foundation resting on partially saturated medium dense sand with $(\mathrm{Dr}=50 \%)$ and matric suction $(9.5 \mathrm{kPa})$

Partially Saturated Dense Sand. Eighteen model tests were performed on foundations with a skirt. Figures (17-19) illustrate the relation between the load and settlement of foundations. Each Figure is plotted for constant foundation width and different skirt lengths of unsaturated matric suction $4.4 \mathrm{kPa}$ (150 mm lowering the W.L), six model tests of unsaturated matric suction $5.45 \mathrm{kPa}$ (300 mm lowering W.L), and matric suction of $7.62 \mathrm{kPa}$ (450 mm lowering the W.L). The figures show that also an increase in ultimate bearing capacity with increasing skirt length and matric suction but more than that of medium dense state and loose sand, which is due to increase in effective stress more than the other sand states.

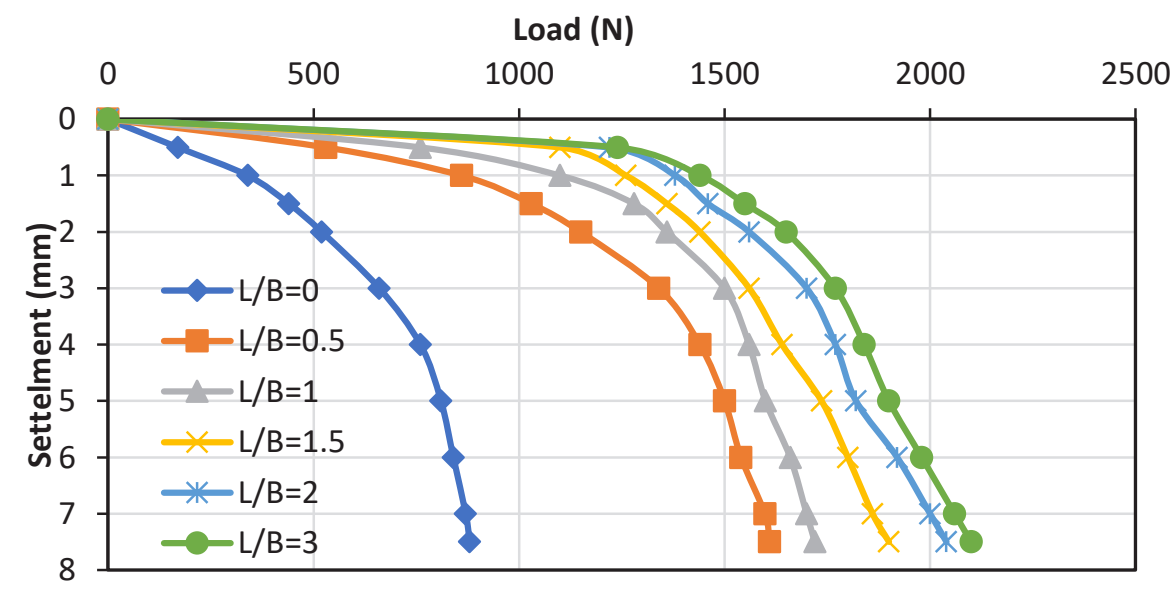

Figure 17. Load vs. settlement for foundation resting on partially saturated dense sand ( $\mathrm{Dr}=70 \%)$ and matric suction $(4.4 \mathrm{kPa})$. 


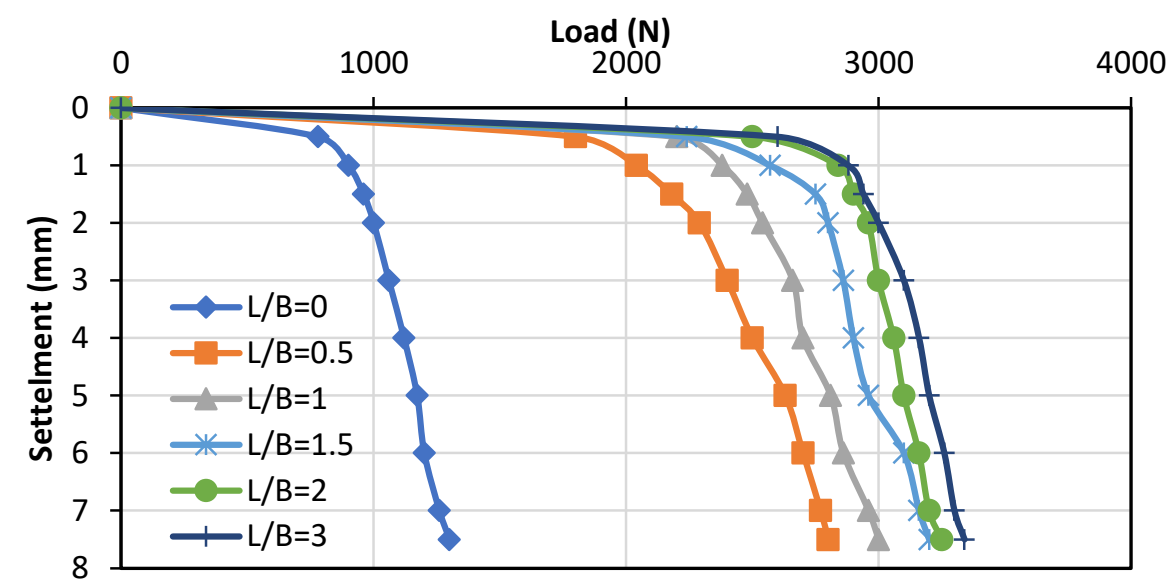

Figure 18. Load vs. settlement for foundation resting on partially saturated dense sand ( $\mathrm{Dr}=70 \%)$ and matric suction $(5.45 \mathrm{kPa})$

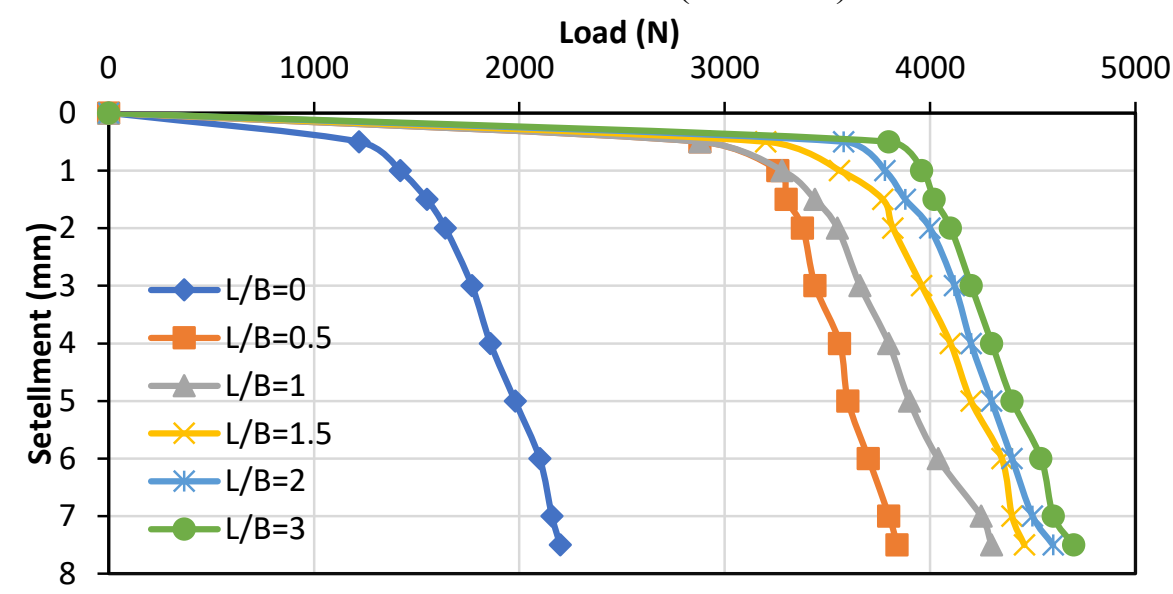

Figure 19. Load vs. settlement for foundation resting on partially saturated dense sand $(\mathrm{Dr}=70 \%)$ and matric suction $(7.62 \mathrm{kPa})$.

Effect of Skirt Length with Different Saturation Condition. Loading experiments models with skirts of various L/B ratios were used to demonstrate the impact of skirt depth on ultimate bearing capacity. It is well known that extending the skirt's depth enhances the ultimate bearing capacity of the skirt foundation for all L/B ratios. With increasing skirt depth, the foundation becomes deeperseated, and the depth of the foundation increases. As the skirt depth increases, the length of the failure plane within the soil increases and increases soil resistance. As a result of the foundation load being transferred to a deeper depth, the ultimate bearing capacity increased, and settlement decreased. Figure (20) shows the ultimate load with different L/B ratios for all the cases.

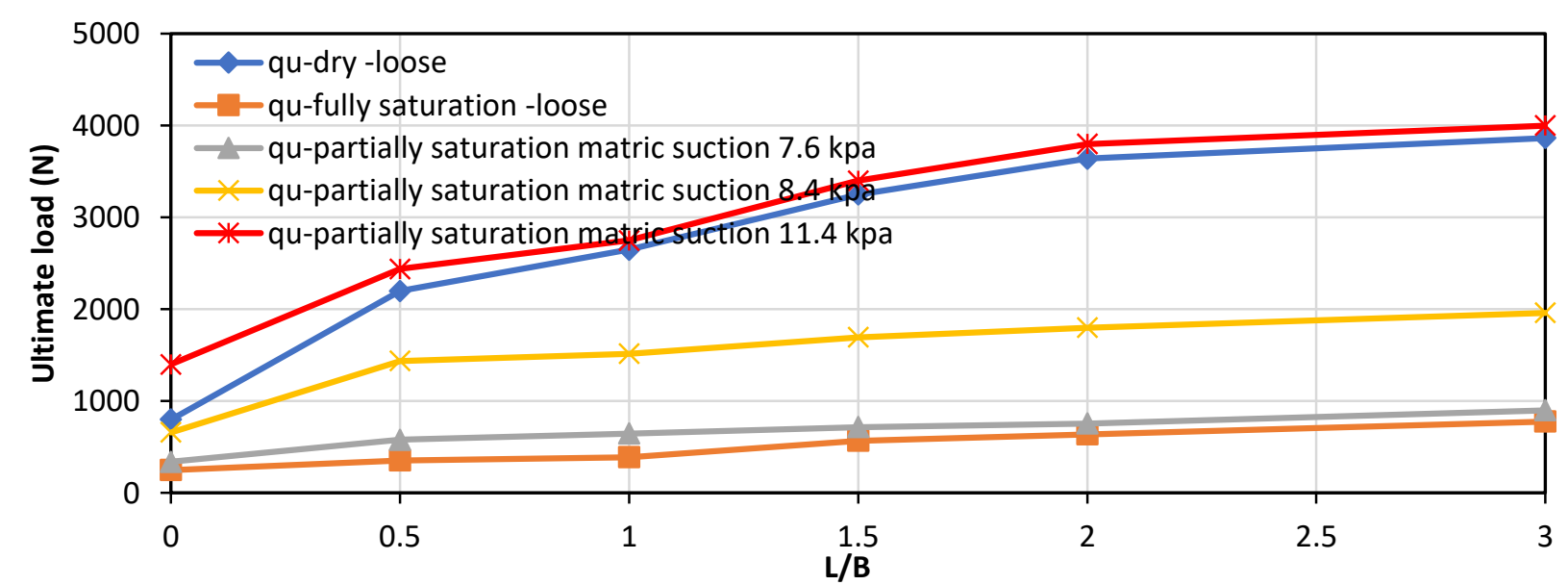

Figure 20. Ultimate load versus L/B ratio for foundation resting on dry, fully saturate and partially saturated loose sand of $(\mathrm{Dr}=30 \%)$ with different values of matric suction. 


\section{Conclusions}

The following major points are concluded from this study:

- Adding a skirt to the edge of conventional shallow foundations supported on the sand with different relative density enhances and modifies foundation efficiency by the increasing loadcarrying capacity and decreasing settlement with different ratios.

- Skirting foundations are used to enhance the load-bearing capacity of foundations on dry, fully, and partially saturated sand. This approach's effectiveness is determined by a number of factors, including skirt depth, relative density, and the interaction of the skirt with the failure plane. The soil saturation condition is relevant parameter in the load-carrying capacity of skirted foundations.

- For all cases loose, medium, and dense state of sand, in partially saturation conditions, there is a significant increase in load-carrying capacity in the medium dense state than in the loose state. So, the increment in ultimate bearing capacity of the dense state is more than that of the medium and loose state.

- With increasing the L/B ratio of the skirt, the foundation becomes deeper, and the depth of the foundation increases, which lead to an increase in the length of failure plain within the soil and increase the soil resistance, which leading in respect to an increment in ultimate loading bearing capacity and decrease in a settlement.

\section{References}

[1] Al-Aghbari, M.Y. and Mohamedzein, Y.A., 2004. Model testing of strip footings with structural skirts. Proceedings of the Institution of Civil Engineers-Ground Improvement, 8(4), pp.171-177.

[2] El Sawwaf, M. and Nazer, A., 2005. Behavior of circular footings resting on confined granular soil. Journal of geotechnical and geoenvironmental engineering, 131(3), pp.359-366..

[3] Al-Aghbari, M.Y. and Mohamedzein, Y.A., 2006. Improving the performance of circular foundations using structural skirts. Proceedings of the Institution of Civil Engineers-Ground Improvement, 10(3), pp.125-132.

[4] Al-Aghbari, M.Y., 2007. Settlement of shallow circular foundations with structural skirts resting on sand. The Journal of Engineering Research [TJER], 4(1), pp.11-16.

[5] Shabana Salih, K. and Joseph, M., 2010. Effect of Structural Skirt on Square Footing.

[6] Ebrahimi, S.G. and Rowshanzamir, M.A., 2013. Experimental evaluation of bearing capacity of skirted footings. Civil Engineering and Architecture, 1(4), pp.103-108.

[7] Fattah, M.Y., Shlash, K.T. and Mohammed, H.A., 2014. Experimental study on the behavior of bounded square footing on sandy soil. Engineering and Technology Journal, 32(5), pp.10831105.

[8] Chandrawanshi, S., Kumar, R., Kaur, D.S. and Jain, D.P., 2014. Effect of skirt on pressure settlement behaviour of model circular footing in medium dense sand. International Journal of Advanced Engineering Technology, 5(2), pp.01-05.

[9] El Wakil, A.Z., 2010. Horizontal capacity of skirted circular shallow footings on sand. Alexandria Engineering Journal, 49(4), pp.379-385.

[10] Vijay, A., Akella, V. and Prasad, B.R., 2020. Experimental Studies and Numerical Validation on Bearing Capacity of Skirted Footings on c- $\Phi$ Soils. In Advances in Structures, Systems and Materials (pp. 85-98). Springer, Singapore.

[11] Mahmood, M.R., 2018. Improvement ratio and behavior of bearing capacity factors for strip skirt footing model resting on sand of different grain size distribution. In MATEC Web of Conferences (Vol. 162, p. 01026). EDP Sciences.

[12] Fredlund, D.G., Sheng, D. and Zhao, J., 2011. Estimation of soil suction from the soil-water characteristic curve. Canadian geotechnical journal, 48(2), pp.186-198.

[13] ASTM Committee D-18 on Soil and Rock, 2010. Standard test methods for specific gravity of soil solids by water pycnometer. ASTM international. 
[14] ASTM, D., 2000. 4253. Standard Test Methods for Maximum Index Density and Unit Weight of Soils Using a Vibratory Table. ASTM International.

[15] ASTM Committee D-18 on Soil and Rock, 2006. Standard test methods for minimum index density and unit weight of soils and calculation of relative density. ASTM International. 